\title{
BICRAL wt Allele
}

National Cancer Institute

\section{Source}

National Cancer Institute. BICRAL wt Allele. NCI Thesaurus. Code C157087.

Human BICRAL wild-type allele is located in the vicinity of 6p21.1 and is approximately $122 \mathrm{~kb}$ in length. This allele, which encodes BRD4-interacting chromatin-remodeling complex-associated protein-like protein, plays a role in SWI/SNF-dependent chromatin remodeling. 